\title{
MIR371B Gene
}

National Cancer Institute

\section{Source}

National Cancer Institute. MIR371B Gene. NCI Thesaurus. Code C158713.

This gene may be involved in translational inhibition or mRNA degradation. 